\title{
DEBORAH JENSON
}

\section{HEGEL AND DESSALINES: \\ PHILOSOPHY AND THE AFRICAN DIASPORA}

Hegel, Haiti, and Universal History. SUSAN BUCK-MORSS. Pittsburgh: University of Pittsburgh Press, 2009. xii + 164 pp. (Paper US\$ 16.95)

Universal Emancipation: The Haitian Revolution and the Radical Enlightenment. NICK NESBITT. Charlottesville: University of Virginia Press, 2008. x + 261 pp. (Paper US\$ 22.50)

These two books have relaunched universal history - not without controversy - as a dominant trope in the fields of colonial history and postcolonial theory. They have also highlighted tensions around the application of a Hegelian philosophical genealogy to Haiti, the first self-emancipated black postcolony, the state ghettoized as "the poorest country in the Western hemisphere," and now the embattled zone of recovery from the catastrophic earthquake of January 2010.

The book-length reedition of Susan Buck-Morss's extraordinarily influential 2000 Critical Inquiry essay, "Hegel and Haiti," is a revelation, on both scholarly and performative levels. On a scholarly level, the essay that rocked the divisions between the most elite European philosophical traditions and the philosophical content of the most radical insurrection in New World modernity is now expanded with two lucid introductions and a compelling essay on universal history. These contributions outline some of the changes that have occurred in the humanities landscape in the decade since Buck-Morss's original observation that "there is no place in the university in which the particular research constellation 'Hegel and Haiti' would have a home” (p. 23).

On a performative level, the book reframes the uncanny blind echo between Buck-Morss's 2000 article and the 1992 essay by a scholar of Cape Verdean origins, Pierre-Franklin Tavarès, in the Haitian journal Chemins critiques, "Hegel et Haïti ou le silence de Hegel sur Saint-Domingue." Buck-Morss had spoken of Tavarès's other work and noted the essay's existence in footnote 72 of the original article, foregrounding that "I have yet to see Tavarès's original article, 
'Hegel et Haïti, ou le silence de Hegel sur Saint Domingue,' in the Port-auPrince journal Chemins critiques 2 (May 1992): 113-31" (p. 843). Yet it seems plausible that few readers of her original essay noticed the oddity of entitling it with a direct translation into English of the first part of the title of a barely accessible article published earlier in Haiti. (In the book, which has a slightly different version of the "Hegel and Haiti" essay, footnote 81 is the corollary to the article's footnote 72, and contains a brief assessment of Tavarès's contributions in "Hegel et Haïti.") Problems of translation, of mutual recognition, and of the dialectic of Euro-American and Caribbean contributions on the Haitian Revolution, are all choreographed in this coincidence.

Although Buck-Morss had conceptualized her argument and research trajectory without knowledge of the contents of the Tavarès article, such latent dialogic relationality resonates with the question of why integration of the historical subtext of the Haitian Revolution into the Hegelian master/slave paradigm has been so crucial in drawing the attention of literary and theoretical scholars to the Haitian Revolution in the first place. Did we have to have Hegel to have Haiti in a certain philosophical sense? When Jean-Jacques Dessalines, in the January 1804 Haitian Declaration of Independence, proclaimed "We dared to be free when we were not free, by ourselves and for ourselves," was it somehow through its prefiguration of a future Hegelian response that it eventually became manifest to theorists of a black Atlantic modernity? Hegel, Haiti, and Universal History is helpful not only for Buck-Morss's frank assessment that "For raising the question of whether Hegel was inspired by events in SaintDomingue, credit must go to Pierre-Franklin Tavarès" (p. 14), but also for her question, "Is it enough to have rescued the Haitian story from absorption into Eurocentricity?" (p. 138). This question rebounds upon itself. In effect, we will be able to assess whether it is enough to have "rescued the Haitian story from absorption into Eurocentricity" when we have done so - but we have not achieved that goal through recognition of the possibility that Hegel's masterslave dialectic may have been inspired by black Atlantic rather than purely European events and sources. An area of the curriculum for Hegel and Haiti ideally would involve structurally bilateral educational processes, historicization of Eurocentric absorptions of Haitian and other anticolonial models, research on Afrocentric counterpoints of influence, universalized access to digital collections of Haitian literary and historical documents, and Creole (Kreyoll) Hegel. The poignancy of the question of the phenomenology of our critical perception is heightened by ongoing inquiry into the linguistic and hermeneutic viability of reading resistance to modern slavery into Hegel's text.

At Nick Nesbitt's farewell conference at the University of Aberdeen on the subject of "Haiti and Universal History" in March of 2010, philosopher Peter Hallward queried whether the notion of a Hegelian inscription of slaves' achievement of subjective and historical autonomy might not be overly generous to Hegel. Of course, this problem of an unwonted privileging of Hegel on 
racially encoded issues was carefully foregrounded in Buck-Morss's original reading. Buck-Morss noted that Hegel, over the years, became increasingly blinded by at least a cultural racism against Africans, and that his philosophy of history has tended to buttress rather than undermine Eurocentrism. But this tension weighs more heavily if even in the Phenomenology of Mind, the institutionalization of freedom in the state takes precedence over active selfmobilization by individuals in the collectivity, emblematized by the agency seized by slaves. Buck-Morss's essay on Hegel and Haiti continues to generate new imperatives to understand not only Hegel's awareness of and reaction to the events of his time, but also the limits of his praise of collective agency. The universal history paradigm, as David Scott noted in Aberdeen, focuses on larger-than-life historical individuals who pursue a universal principle and around whose trajectory a world spirit of movement and change can be mapped. The very notion of "Hegel and Haiti" implicitly seems to harness the canonical author, the universal philosophical individual, Hegel, to the Afro-diasporic nation of Haiti. Does "Haiti" represent the state in this equation, or a nonstate in relation to the political identities of Euro-American states, or the masses, or the personification of a universal principle through the abstract figure of the slave and his or her pursuit of freedom?

Perhaps the above options should be rephrased through the pairing "Hegel and Dessalines" when one considers the journalistic accounts that brought Haiti to Hegel's attention. Probing journalistic sources for Hegel's possible referential fertilization of his philosophical paradigms was a brilliant innovation on Buck-Morss's part; as she noted, journalism made the Haitian Revolution into "the crucible, the trial by fire for the ideals of the French Enlightenment” (p. 42) about which every member of the European bourgeois reading public knew. Hegel was particularly explicit about the influence of newspaper reading on his worldview, noting that over the newspaper, "'One orients one's attitude against the world and toward God [in one case], or toward that which the world is [in the other]"' (cited on p. 49). Buck-Morss believed that the paper Minerva, run by Archenholz, was particularly key in Hegel's contemplation of slavery's dynamics: "For a full year, from fall 1804 to the end of 1805, Minerva published a continuing series, totaling more than a hundred pages, including source documents, news summaries, and eyewitness accounts, that informed its readers not only of the final struggle for independence of this French colony - under the banner of Liberty or Death! - but of events over the previous ten years as well" (p. 42). Since I personally have been inspired by Buck-Morss's work to pursue the history of the U.S. publication of Haitian Revolutionary documents in detail, I was particularly curious about the nature of these documents, and what they might reveal about Hegel's specific knowledge of Haiti and its thinkers.

With the help of a research assistant from Duke's doctoral program in German, Chunjie Zhang, I ascertained that Minerva's Haiti pieces were a 
mixed bag, combining hostile and sometimes racist accounts with notable documents produced by the leader Jean-Jacques Dessalines and his secretaries. As Buck-Morss notes, Archenholz published a translation of excerpts from Marcus Rainsford's 1805 Historical Account of the Black Empire of Hayti, which presents a stirring interpretation of the radical import of the Haitian Revolution and of the historical merit of Toussaint Louverture. Yet a very substantial chunk of the 100-plus pages noted by Buck-Morss came from a single text, Dessalines's 1803 military field journal, which has eluded ideological and philosophical readings to date, as it concentrated primarily on military strategy and events. Other articles outlined massacres of the French, or the experiences of passengers on ships seized by the Blacks in the course of the hostilities. Minerva also featured a long excerpt from F.J. Dubroca's defamatory rants against Toussaint Louverture and Dessalines. A widely published American article on a ball hosted by Lady Dessalines in Haiti included fascinating details about the new Haitian state, but also presented it as a curiosity or an object of mockery.

But Minerva unquestionably gave strong emphasis to the texts produced by Dessalines, whose name appears at least sixteen times in these documents. Examination of the texts by Dessalines in Minerva allows one to deepen the case first made by Buck-Morss not just between Hegel and Haiti, but also between Hegel and Dessalines's worldview, and the ramifications of that worldview for universal history. The much-observed fact that Hegel was more open to the fundamental parity between the stakes of freedom for slaves or members of the African diaspora and for any other world citizen in his early texts than in his later writings (see Buck-Morss, pp. 73-74) can perhaps be credited to the brief influence of Dessalines as a striking political thinker and voice. Dessalines's two most important texts - the Haitian Declaration of Independence and the April 28, 1804 text in which he triumphally asserted "Yes, I have avenged America" - appear in the February 1805 edition of Minerva, which is to say more than a half a year later than their publication in the United States. But contrary to their dissemination in the United States, they were published together, from pages 276 to 293, in a mini-Dessalinian anthology. This anthology-style presentation would have permitted the reader to explore Dessalines's texts in a singularly sustained and literary manner. In the April 28 proclamation, Dessalines evoked the Europeans as the "plague of the New World," in response to which, "the irritated genius of Hayti, arising from the bosom of the ocean, appears." For the Europeans who would dare to try to reconquer Haiti, it would be a better fate for the ocean to simply "swallow them up in its deepest depths" than for them to be "devoured by the anger of the children of Hayti." Consider the echoic relationship between the famous line in the Philosophy of Right, "Even if I am born a slave, ... still I am free in the moment I will it" (cited in Buck-Morss, p. 61) and Dessalines's assertion that the Haitians "had resuscitated freedom by infusing their own blood into 
it," that they were "proud to have recovered their freedom, jealous to maintain it, and determined to overcome anyone who would try to ravish it from them again." As an example of the document's ironically proto-Hegelian resonance, which we could more aptly read as the proto-Dessalinean resonance of the Hegelian master-slave dialectic, Dessalines claimed that the French had brought the qualifying epithet of "slave" on their own heads: "Slaves! ... Let us leave that qualifying epithet to the French themselves: they have conquered to the point of ceasing to be free." To his people - in the German translation, the second part of the Haitian Declaration of Independence opens with the word "Bürger!" - Dessalines says that in working toward his people's freedom, he had constructed his own happiness, and also that he was rich only in his people's freedom. For these reasons, he claims that his name, Dessalines, had become a motif of horror for "all people who desire slavery." Hegel scholars would do well to compare the Haitian Declaration of Independence in the British archives, http://www.nationalarchives.gov.uk/documentsonline/ haiti.asp\#research, to the translation Hegel was reading in Minerva, Vol. I, pp. 276-93. Buck-Morss's work makes palpable the eruption of Dessalines's voice into Hegel's contemporaneous worldview, above all in the phenomenon of self-consciousness comprehending itself as free. Ultimately it is hard not to agree with Buck-Morss that there is something of Haiti in Hegel - even, arguably, a lot of Dessalines in Hegel.

The new material in the second half of Hegel, Haiti, and Universal History begins with a nod toward Sibylle Fischer's notion of "modernity disavowed" and a statement that "Present realities demand such historical remappings as an alternative to the fantasies of clashing civilizations and exclusionary redemptions" (p. 79). It moves on to a fascinating continuation of Buck-Morss's work on the relationship of freemasonry to Hegel and Haiti - inspired by the discussion of freemasonry in Tavarès's work - set in a larger exploration of whether slavery could in fact have taken root in Europe, rather than being outsourced to far-off colonies. Buck-Morss argues for an understanding of slavery on a long continuum of labor practices, with a specifically capitalist modern form. The focus of this material is primarily cultural rather than theoretical. If there is a "big bang" in the interpretations in this section of the book, it is an evolving definition of universal history as something that emerges not in "the mediation of collective cultural identities," but in "the historical event at the point of rupture" which gives expression to "a humanity that goes beyond cultural limits" (p. 133). Yet the appeal of the Haitian Revolution as universalizing "rupture" is undermined by the acuity of cultural mapping in Buck-Morss's Haiti work, which ultimately confirms not a Romantic escape from hegemony, but a tissue of related conditions and strategies, and of the philosophies, institutions, and technologies that allow meaning to travel from one location to another.

In an ideal "Hegel and Haiti" area of the curriculum, the texts of European philosophers would be sounded for the influence of Haiti, and tested for the 
viability of their emancipatory paradigms in relation to Haiti, and that is in effect what Nick Nesbitt adds to the field in his excellent new book, Universal Emancipation: The Haitian Revolution and the Radical Enlightenment. In this book Nesbitt broadly develops, in masterful strokes, the project that germinated in his now famous essay, "The Idea of 1804" in the 2005 "Haiti Issue" of Yale French Studies. His stated resolution at the outset is to "seek to recover what 1804 might have become (or became only in the sheer exteriority to our world of the Haitian rural peasantry, the moun andeyo" " [p. 4]. The book is motivated by a positive notion of human rights, in an era in which Nesbitt feels (following Gauchet) that human rights have "achieved hegemony over the concept of the political" (p. 10). If the underlying core of Buck-Morss's work on universal history is culturalist, Nesbitt's nexus of questions and models comes from political philosophy; this book is a sophisticated sounding of a vast field of political thinkers, including Spinoza and Habermas and Genovese, against the tensions of Haiti's radical enlightenment. Readers looking for connective tissue between Haiti and Zizek, Laclau, and Butler will find their source here; other readers may realize that even if they had not sought those connections, they should start now with Nesbitt's guidance.

Yet Universal Emancipation also has historicist depths and innovations. One of the most remarkable sections of the book, "Mali, 1222," is a historicization of human rights discourses to the Mandé world and Soundiata Keïta's "Mandé Charter." The flexibility of a research methodology allowing the marshaling of such analogies and counterpoints to Haiti, in theoretical and historical terms, exemplifies some of the most worthy ambitions of universal history in its new millennial guise. As Nesbitt notes, Toussaint Louverture's participation in Enlightenment debates as played out in the colonial field of human rights is simply a "key element in a variegated knowledge system spread across the entire Atlantic world, one that actively debated the nature of human freedom from Salamanca to St. Marc, Königsberg to Les Cayes, Timbuktu to Tiburon" (p. 60). Ayibobo! Nesbitt's work is one of the first truly satisfying extensions of the work begun in Srinivas Aravamudan's Tropicopolitans, except that rather than tropicalizing the Enlightenment, Nesbitt globalizes it.

Nesbitt takes on Michel-Rolph Trouillot's challenge of the Haitian Revolution as "unthinkable history" in a chapter called "Penser la Révolution haïtienne" (Thinking the Haitian Revolution), a complex navigation of Kantian and Hegelian universalism. This chapter presents a particularly provocative interface with Buck-Morss's Hegel, Haiti, and Universal History, notably in the section called "Hegel and Haiti Reconsidered." After analyzing the linguistic possibilities for evocations of slave, bondsman, and serf in Hegel, Nesbitt reads slave revolts in ontological and ethical terms, managing to bring Hegel to life as an imaginative and responsive philosopher of slavery in several instances, and in the process reconfirming the vitality of Buck-Morss's project. 
The notion of radical exteriority, radical potentiality, or rupture, arguably preoccupies Nesbitt's book just as it does that of Buck-Morss, although it does not come through the front door of theory, but through the back door of a somewhat exoticized relationship to postrevolutionary Haitian cultural history. Just as not all readers will be comfortable with the notion of the Haitian Revolution as a "Miraculous Intervention" (p. 124), the category of the extreme exteriority of the Haitian rural peasantry is arguably more static and symbolic here than it need be, especially in light of such trends as the ever-increasing flux of rural populations in the capital, and the omnipresence of cell phones in even deeply rural spaces. The quest to imagine what 1804 might have become is on some level a minute failure to imagine what 1804 actually was, not philosophically or politically, but anthropologically and sociologically.

Nesbitt's Universal Emancipation and Buck-Morss' Hegel, Haiti, and Universal History are among the most innovative and stimulating critical assessments of the Haitian Revolution in a crowded field; aptly read in dia$\log$, and yet for contrast, they will have the staying power of the works that change the contents of the larger bibliography of required readings to understand the Haitian Revolution and its European philosophical interlocutors.

\section{REFERENCES}

ARAVAMUdAN, SRINIVAS, 1999. Tropicopolitans: Colonialism and Agency, 1688-1804. Durham NC: Duke University Press.

ARCHENHOLZ, JohANN WiLLEM VON \& FRIEDRICH A. BAN (eds.), 1805. Minerva. Vol. I. Hamburg: Hoffmann.

BUCK-MORSS, SUSAN, 2000. Hegel and Haiti. Critical Inquiry 26(4):821-65.

Hegel, G.W.F., 1967. The Phenomenology of Mind. Trans. J.B. Baillie. New York: Harper Torchbooks.

RAINSFORD, MARCUS, 1805. An Historical Account of the Black Empire of Hayti. London: J. Cundee.

TAVARÈS, PierRe-FranKLin, 1992. Hegel et Haïti ou le silence de Hegel sur SaintDomingue. Chemins critiques 2:113-31.

\section{DEBORAH JENSON}

Department of French Studies

Duke University

Durham NC 27708, U.S.A.

$<$ deborah.jenson@duke.edu> 
Reproduced with permission of the copyright owner. Further reproduction prohibited without permission. 